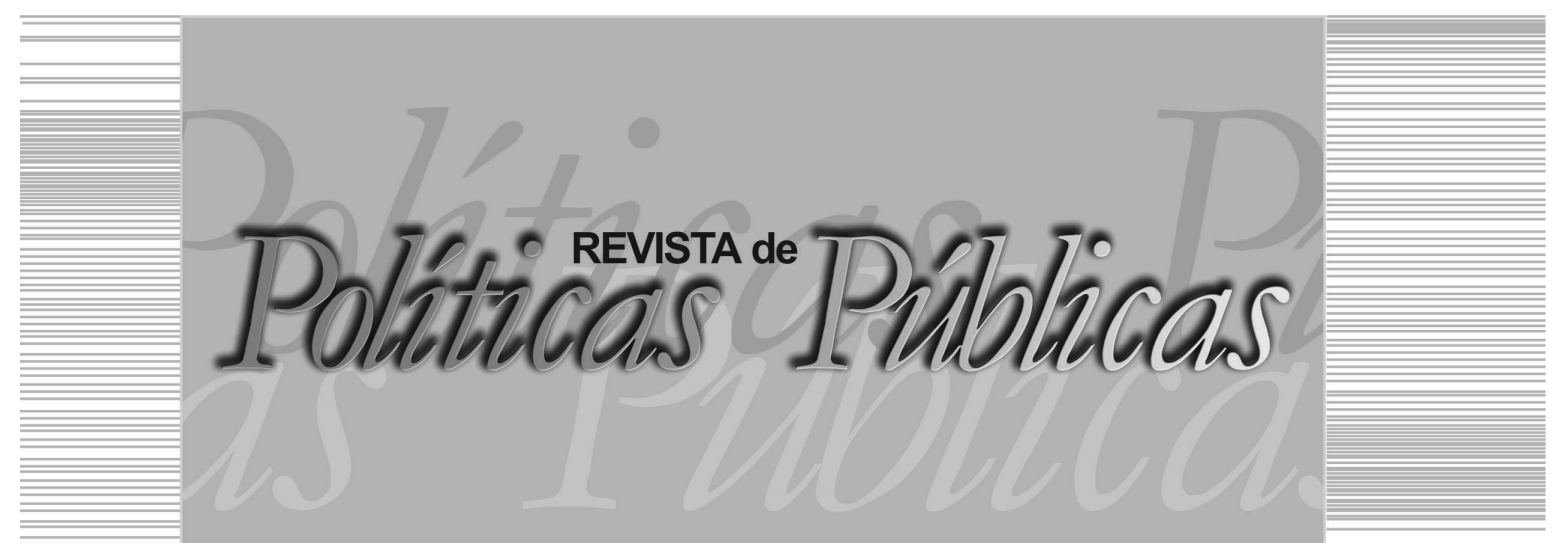

\title{
PUBLIC BROADCASTING SERVICES IN THE UNITED STATES AND BRAZIL: history, funding and new technologies
}

\author{
Melissa S. Moreira Rabêlo ${ }^{1}$ \\ Universidade Federal do Maranhão (UFMA) \\ Martha Garcia-Murillo ${ }^{2}$ \\ Syracuse University \\ Carlos Agostinho Almeida de Macedo Couto ${ }^{3}$ \\ Universidade Federal do Maranhão (UFMA)
}

\section{Resumo}

O artigo traz a problemática do sistema púplico de televisão no Brasil e Estados, no que se refere ao seu modelo de financiamento e política, fazendo uma relação com as novas tecnologias no setor e as mudanças de comportamento da população em relação ao meio televisão.

Palavras-chave: Televisão pública, política, novas tecnologias.

\footnotetext{
Comunicação Social, habilitação Relações Públicas, Doutoranda em Políticas Públicas pela Universidade Federal do Maranhão (UFMA), Professora assistente do Departamento de Comunicação Social da UFMA. E-mail: melissamoreira@yahoo.com

2 Jornalista, Doutora em Political Economy and Public Policy na University of Southern California, Professora da School of Information Studies of Syracuse University. E-mail: mgarciam@syr.edu /_Syracuse University: 114 Hinds Hall, Syracuse, NY 13244-1190

3 Comunicação Social, habilitação Jornalismo, Doutor em Políticas Públicas pela UFMA, Professor adjunto do Departamento de Comunicação Social da UFMA. E-mail: carlosacouto@uol.com.br / Universidade Federal do Maranhão - UFMA: Av. dos Portugueses, 1966, Bacanga - São Luís - MA, CEP: 65080-805
} 


\title{
PUBLIC BROADCASTING SERVICES IN THE UNITED
}

STATES AND BRAZIL: history, funding and new technologies

\begin{abstract}
The paper presents the problem of the public broadcasting system in Brazil and US, with regard to its financial model and policy, making a connection with the new technologies in the industry and changes in the behavior of the population in relation to the television media.

Key words: Public television, policy, new technologies.
\end{abstract}

\section{INTRODUCTION}

The goal of this study is to examine the public broadcasting business models in Brazil and United States in order to understand how access policy was established, how content is developed and financed, and whether or not technology could lead to significant changes.

Mass media is fundamental to a nations' cultural diversity, its freedom of information and speech, its education, and ultimately, the strength of its democracy. Countries have developed different models for the creation and distribution of public media.

In this paper, we contrast the history, development and business models of the public broadcasting services of two countries, Brazil and the United States, and the manner in which they are affected by technology.

Brazil is among the countries with the lowest access to public broadcasting in the world, only accessible in a few cities. It is surprising that a country that has continued to develop both economically and politically still has such poor access to free and public information.

This stands in contrast to the United States, a developed economy that has almost universal access to public broadcasting. According to the website for the Corporation for Public Broadcasting (CPB, 2012), over 95 percent of the U.S. population is able to access content from the public broadcasting service.

In spite of their economic differences, these two countries share the same set of economic beliefs, specifically their support for free markets. 
Examining the contrast between two nations with similar economic philosophies can help us understand the different ways in which the state and the private sector interact in the public broadcasting sphere, the manner in which they are funded and how they are affected by new technologies.

The next section reviews the history of the two systems. The third section contrasts their business models. Section four provides a brief review of new technologies and their impact on public broadcasting. The fifth section presents the results of a survey of consumers in the United States and Brazil, which was designed to get a sense of the viewing habits of the populations of the two countries. Based on these results and on the history and business models of the public service content of these two countries, we then provide policy recommendations.

\section{A BRIEF HISTORY OF THE PUBLIC BROADCASTING SERVICE IN THE UNITED STATES AND BRAZIL}

The ways in which the U.S. and Brazilian public broadcasting service develop content and finance their operations differ significantly.

In the United States, public channels are available in all states through local stations. Funding comes from the public and the private sectors, with small support from the government.

In Brazil, the public communication service is licensed and regulated by the government to the communities, legislatures and universities that run public TV stations. Funding for both content and operations comes entirely from the state, which prevents local stations from attracting additional funding from other sources. This results in relatively unappealing content due to the limited resources provided by the state.

\subsection{The public broadcasting service in the United States}

The North American model of communications emerged as a free market enterprise that soon encountered difficulties, primarily because of the scarcity of the radio spectrum. As Ramos (apud SANTOS; SILVEIRA, 2007, p. 61) states:

In the beginning, the explosion in the number of radio stations caused chaos on the air. Until mid-1923 there were 500 stations in the 
United States, reaching two million people. In 1924, the number
grew to 1,105 radio stations, sharing the same 89 available fre-
quencies. The North American scenario frightened the English.
Opinions rejecting the American model were commonly heard,
such as that of the English radio pioneer R. N. Vyvyan, who was
horrified at the lack of regulation, the interference between radio
signals and the mass use for advertising purposes.

Broadcasters who wanted to maintain a market free of regulation argued that having more stations was beneficial to the population because it gave citizens multiple outlets to express their opinions, while keeping them better informed. However, spectrum interference was a serious problem that needed to be solved. There was very little government regulation of broadcasting until 1927 , when the Federal Radio Commission was set up with very few powers. (BAMOUW, 1966). There was, for example, no control over content. Almost 100 percent of the radio frequencies had been allocated to commercial stations, with a few left over for educational broadcasters, many of them universities. (SHEPPERD, 2014). Unlike the private sector, universities that operated stations believed that the radio was a mechanism that allowed the public to be informed and educated (WITHERSPOON et al., 1987). This view differed from what private broadcasters such as National Broadcasting Company (NBC) and Corporation Broadcasting System (CBS) had in mind, a national clear channel with little interest in developing civic programming. (DOUGLAS, 1989).

Due to the prevalence of the commercial stations, there was great concern about censorship of the new medium and potential abuses from the state. (SANTOS; SILVEIRA, 2007).

It was thanks to John Studebaker, a former school superintendent later to become the Commissioner of Education in 1934, that federally mandated public service broadcasting was implemented in the U.S. He was able to unify previously decentralized educational broadcasting stations through the National Association for Educational Broadcasting (NAEB). (SHEPPERD, 2014). Through the Federal Radio Education Committee (FREC), which Studebaker had helped to establish, the educational broadcasting efforts evolved into the public broadcasting service we know today.

During these early years of the sector, broadcasters participated in industry and government conferences that led to legislation for broadcasting that would serve the public interest. (ROWLAND, 
1986). The notion of public Interest, which was being debated then, was rather ambiguous. Public interest was understood as a convenience with the market as the main organizing force to ensure equality in broadcasting, both in transmission and in reception. (SANTOS; SILVEIRA, 2007). It was thus necessary to decide which of these alternatives would best serve the public. The objective was to establish a public broadcasting service to serve the interests of the listeners, and not the interests, convenience or needs of the broadcaster. At the time, there was a proposal to set aside 25 percent of the spectrum for not-for-profit and educational programming, an initiative that was never supported by the administration or the Congress. (ROWLAND, 1986). As expected, commercial stations opposed this legislation, as they would have lost spectrum frequencies. There was a belief that commercial stations would be able to cooperate with noncommercial and educational institutions to provide public service-type content, a prospect that was never realized and a failing that took time to be recognized. (ROWLAND, 1986). The designation of noncommercial connoted an alternative of secondary importance, and educational was equated with the extension of university stations' formal educational objectives, which in turn were equated with boring and uninteresting programming. (ROWLAND, 1986). Over time, however, these noncommercial stations became increasingly popular and gained the respect of the population and the government, but in spite of this progress, the initial expansion of these stations was limited to a higher spectrum frequency, and later to FM, which, at the time, was not widely accessible because most radios were designed to received only AM signals. As a result, they could reach only a small audience. (ROWLAND, 1986).

The CPB was not created until 1967, with the passage of the Public Broadcasting Act. Prior to that, many noncommercial licenses operators began to pressure the government for more permanent funding allocations, which led to the creation of the Carnegie Commission, which served as the catalyst for the passage of the Act. (ROWLAND, 1986). The term that was used for these stations shifted from noncommercial educational to public. The Act led to an expansion in the number of public stations, both radio and television, and the creation of the Public Broadcasting Service (PBS) and National Public Radio (NPR).

This public broadcasting network is now composed of a complex web of organizations operating Internet sites, and radio and 
television stations designed to be free from state intervention. Its structure, present in all states, depends on local independent stations, integrated by national networks responsible for the exchange of content through the national CPB, the PBS and NPR. The CPB, PBS and NPR are independent of each other and of local public television and radio stations across the U.S.

Public broadcasting in the U.S. has a universal service mandate - to provide all Americans with free, over-the-air access to public broadcasting's programming and services. Today, the system is changing in a process described on the CPB's site (2016)

\begin{abstract}
A dynamic public media is transitioning to meet the information needs of, and connect with, a much more diverse America in ways that honor our mission. A dynamic public media is working to reach and engage with audiences, when and where they choose, with content important to their lives. A dynamic public media is partnering with entities that are bringing diverse new voices and new ideas to the table.
\end{abstract}

According to the Public Broadcasting Act of 1967, the CPB has the responsibility, among others:

- To encourage the growth and development of public radio and television broadcasting, including the use of such media for instructional, educational, and cultural purposes.

- To complement, assist, and support a national policy that will most effectively make public telecommunications services available to all citizens.

- To ensure that all citizens of the United States have access to public telecommunications services through all appropriate available telecommunications distribution technologies. (UNITED STATES, 1967).

The public broadcasting service in the United States differs from that in other countries, as it relies primarily on non-state funding. The government prefers market solutions, and the discussion on the issue is often about deregulation. Nevertheless, the public communications service is found in all of the states, due to the presence of strong local stations.

Today, according to the CPB's website, over 95 percent of the U.S. population is able to access public broadcasting's over-the-air 
signals. More than 118 million Americans tune into PBS stations on a monthly basis, and 37 million listen to public radio each week.

The goal of the public broadcasting service in United States is to develop culturally diverse programming with high-quality, entertaining, informative and educational content.

Public broadcasting in the U.S. is controlled by local stations that generate or purchase programming from other local stations. They have the autonomy and authority to select content and schedule programs. The $\mathrm{CPB}$ also provides programming and funds to producing entities and independent producers.

Furthermore, local public television stations can obtain their programming from other sources, independent of the CPB. According to the CPB website, PBS, American Public Television, the Independent Television Service and the National Education Telecommunications Association are some of the alternative sources from which local stations can get programs in order to build their own programming, and they have the option to produce their own content or access that of independent producers.

These organizations offer thousands of hours of primetime, educational and cultural content for children, which they can access via satellite stations nationwide or purchase on a title-by-title basis from other member stations.

The system is thus diverse, with little funding from the government, and it has been able to adapt to the needs of the population.

\subsection{Public broadcasting in Brazil}

The Brazilian communication service was consolidated with a commercial format in 1950. The public service was born with the same guidelines that were put in place for commercial stations, without government or private financial support. Inspired by the British model, public communication in Brazil is conceived of as a public service, which bestows greater responsibility on the state to support it.

The Brazilian public television operator, Empresa Brasil de Comunicação (EBC), was founded in 2007, a result of the merger of two public broadcasters: Radiobrás and TV Educativa (TVE). This was the first time in the sector that the government attempted to cre- 
ate a network for public communications in the country, intended to create a free space for the participation of various organizations (foundations, community centers, universities and not-for-profit institutions) and society in general. It opened a forum for public content in a sector dominated by commercial enterprises. The network of public broadcasters in Brazil is thus composed of a heterogeneous group of stations with different purposes and characteristics. The purpose of this service is

[i]ndependence from political intervention in the development of programming and content as well as independence from economic interest exerted through advertising. It gives society control of the programming and guidelines; it intends to be an agency of representation with actual power; to have unique programming for artistic, cultural, informative and scientific purposes, seeking to strengthen citizenship and national identity; to have a light, flexible production structure, with low production costs by absorbing regional and independent productions. (BRASIL, 1988).

Article $223^{\circ}$ of the 1988 Federal Constitution of Brazil makes it clear that it is the task of the executive power to grant and renew concessions, permissions and authorizations for the broadcasting of sounds and images, as long as they respect complementarity among private, public and state services.

However, there are scholars in Brazil who argue that the Constitution intends to create a balance in broadcasting between the communications media managed by commercial enterprise and the public or non-commercial sector. "Thus complementarity suggests a change in infrastructure, which could harm the interest of the hegemonic groups in communications." (LOPES, 2011, p. 8). In other words, this division into different categories of communication would prevent domination by commercial interests.

The Brazilian Constitution divides the communication services into three spheres that complement each other:

- private, which consists of commercial stations funded by advertising,

- public, which is composed of community- and university-led stations,

- non-commercial, which consists of stations funded by the state or foundations. 
The Constitution also dictates which stations are to show programming from government entities like the legislature and the courts, and establishes that funding shall come from the federal government, states or cities.

The public communications service thus consists of channels backed by government investment; together, they form a group of educational, legislative, community and university channels that are politically and conceptually independent, without government or private sector intervention in editorial decisions. However, they do not attract the same audience interest as the commercial stations. The public channels are more constrained in their operations, as they have to comply with laws and regulations that put limits on advertising and funding.

In Brazil, the spectrum is considered a public resource, which obliges commercial stations to comply with public service obligations. This has led researchers such as Valerio Brittos and Murilo César Ramos (apud LOPES, 2011) to argue in favor of the division of the communication service into three spheres - state, private and public - which would allow commercial stations to ignore the production and distribution of public service programming. This loophole, Ramos and Brittos (apud LOPES, 2011) beleive, will result in commercial stations' failing to produce educational and cultural content. To them, the commercial sector exists because of the concession that was granted to them by the state, authorizing them to exploit the spectrum. For these scholars, the 233 Constitutional article also suggests the creation of a state category different from the public category.

It should be stressed that Article $3^{\circ}$ of the 233 Provisory Measure of the public TV law proposes fostering "[...] the development of citizenship, the consolidation of democracy, and participation in society, ensuring citizens' right to information." (BRASIL, 1967). It requires that mass media, be it public or private, provide a public service to society. It mandates that public service broadcasting should abide by three rules: (a) continuous service, (b) flexibility, requiring the continuous improvement of service, based on the assessment of needs and technological progress, and (c) equal access to all citizens. (JAMBEIRO, 2000).

The current status of public television in Brazil violates the third article of the country's Constitution, which says that citizens 
have a right to free public TV via all types of electronic mass media. This is because the main public television channels owned by the state do not reach the entire country with a free signal. Brazil has 27 states and 5,507 cities, but only in a few cities in five states and the country's capital does the population have access to a direct and free public TV signal. Today, public stations use the infrastructure developed during the first years of television broadcasting in Brazil, which is now obsolete and incomplete. In seventeen states, transmission is conducted by state and municipal education television stations via a direct and free TV signal, but these do not always offer the full menu of programs offered by the federal service because these stations have their own local programming. Access to the complete range of public TV programming is possible through private cable or satellite services, but, according to Anatel (the Brazilian Telecommunication Agency), only 27 percent of the population in 2013 had access to cable TV. This means that in most states citizens have to pay for this public service. This is problematic because in Brazil the majority of the population cannot afford to pay for TV services; therefore, there is room for the Brazilian state to expand access to free public channels through investments. This could advance education, culture and democracy through a widely accessible communications service.

\section{BUSINESS MODELS FOR PUBLIC BROADCASTING IN THE US AND BRAZIL}

\subsection{Funding of public broadcasting in the US}

The funding model for public broadcasting in the United States that prevails today emerged at a time when the universities operating educational radio stations provided funds for programming and operations through their own budgets and through grants that they obtained from entities such as the Rockefeller Foundation, and when Studebaker was able to secure funds from entities such as the Carnegie Corporation. (SHEPPERD, 2014). Funding from the government began when President Roosevelt supported the funding of three educational radio programs from the Educational Radio Project, which, to everyone's surprise, received 400,000 letters of support from the public. (SHEPPERD, 2014). 
In fact, state funds for educational programming did not start until 1958, when Title VII of the National Defense Education Act (NDEA) provided $\$ 3$ to $\$ 5$ million a year for research and experimentation on the educational uses of film and broadcast media. (BLAKELY, 1979).

In 1962, the All-Channel Receiver Act required television sets to have VHF-UHF reception capacities, while the Educational Television Facilities Act (ETFA) provided matching funds available for the construction of new stations. These actions were made possible thanks to President Kennedy's attention to the public interest of noncommercial media. Throughout the 1960s, government funding for these noncommercial educational stations came primarily from state and local governments, but funding from foundations was still an important source of revenue for them. (ROWLAND, 1986).

Something that has always prevailed in the United States public broadcasting service is a minimalist policy towards public service broadcasting, which poses a constant threat of its being abandoned in favor of a market-based service. (ROWLAND, 1986). In 1983, for example, the CPB lost 20 percent of its federal funding. In 1985, there were efforts to allow for the use of advertising to fund public radio and television. (ROWLAND, 1986).

Even though the Carnegie Commission recommended the allocation of permanent funds for public licenses, this was not actually realized. Stations became more efficient by implementing national interconnections and programming agencies that improved the technical deficiencies of program distribution and enabled the simultaneous airing of programs.

As in Brazil, public broadcasting has never been a priority in the United States communication policy. (ROWLAND, 1986). Thus, the public communications service in the United States is supported with funds from what are known as underwriters, which are promotions of commercial entities.

The Public Broadcasting Service is a private, non-profit media enterprise owned and operated by member stations; it distributes programming to 348 public television stations across the country and is funded by the CPB and member stations. NPR is a not-for-profit radio enterprise that produces and distributes programs. It is funded by member stations. 
The CPB, which does not transmit, produce or distribute content, is an independent entity created by the federal government in 1968, responsible for receiving financial resources from the government to be transferred to local broadcasting stations. According to the CPB's website, 232 (40 percent) of the 577 stations are considered rural; of these, 62 are public television and 170 are public radio. (GRIFFEN, 2009). Rural stations rely more on CPB funding than urban ones.

The circumstances of public broadcasting in the U.S. differ significantly from those of other services in the world. The U.S. government did not participate ostensibly in forming the system; it acted basically as a regulator, mediating interests and conflicts.

Gráfico 1 presents the amount of funding that the government has provided to public broadcasting over the last 42 years. It shows some increases in its early history, but funding has remained stable for the last 20 years.

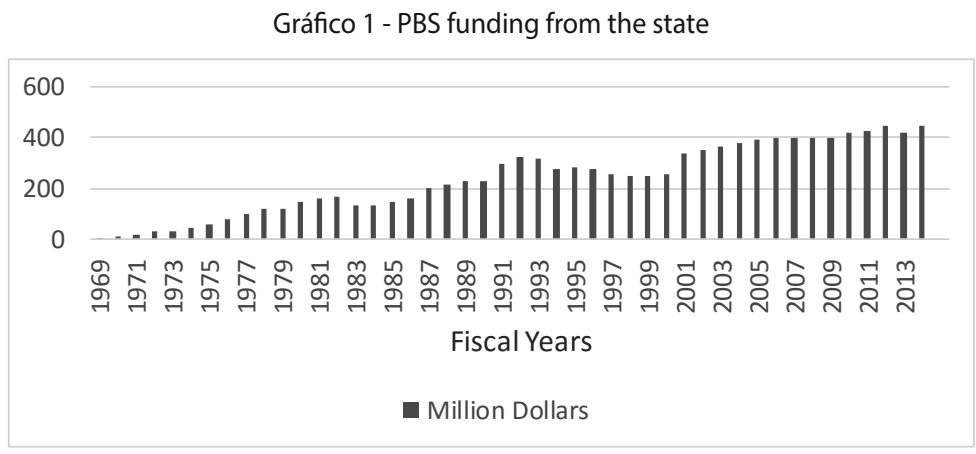

Source: CORPORATION FOR PUBLIC BROADCASTING. Annual Report 2014. Washington, D.C., 2014. Disponível em:<http://www.cpb.org/annualreports/2014/>. Acesso em: 14 jan. 2014.

Gráfico 2 shows the sources of revenue for public broadcasting in the United States. As can be seen, the majority of funding comes from non-government sources. The private sector's contributions include both individual donors and corporations. 
PUBLIC BROADCASTING SERVICES IN THE UNITED STATES AND BRAZIL:

history, funding an new technologies

Gráfico 2 - Public broadcasting revenue by major source

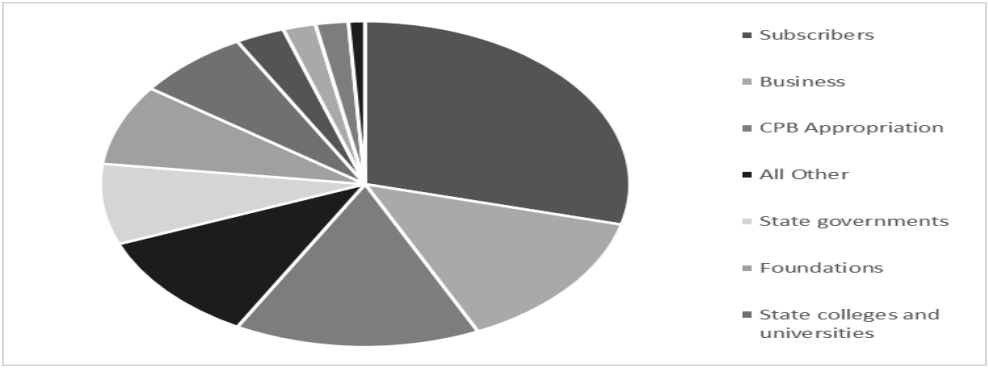

Source: CORPORATION FOR PUBLIC BROADCASTING. Public Broadcasting Revenue Fiscal Year 2013. Washington, D.C., 2013.

In fiscal year 2011, the CPB provided more than $\$ 103$ million, which represented over 24 percent of total appropriations; \$413 million came from non-federal funds, including \$115 million in state funding; $\$ 57$ million came from colleges and universities; $\$ 18$ million from foundations; $\$ 46$ million from local businesses; and $\$ 135$ million from individual donors.

Today, the American public communications service is composed of 1,300 non-commercial local radio and television stations, which are supported by the CPB and others sources. They work together, and with hundreds of national and local producers and community partners, to ensure that Americans have universal high-definition access to non-commercial programming focusing on the needs of the audience, including children, minorities and low-income citizens. The stations are locally managed and programmed, and in some rural areas they are the only source of local, national and international news and discussions of political and cultural topics. Unlike the situation for other public communications services in the world, the government is not the main source of funding. On average, the federal resources correspond to less than 14 percent of the broadcasters' budget, and the rest, about 86 percent, comes from local sources.

\subsection{The Brazilian business model for public broadcasting}

From the outset, Brazilian public radio and TV broadcasters operated with insignificant budgets. In the 1960s, the debate about the educational mission of broadcasting became stronger, with pres- 
sure from organizations such as National Educational Television (NET) and the NAEB.

In Brazil, the business model relies almost exclusively on funding from the state. The EBC is a public enterprise, and its resources come from taxes and funds allocated for the development of the country's public communications. Others sources of revenue that have been considered are the sale of programs to other TV stations, the sale of services to Executive Television (the government's television channel, which releases information from the federal government), the sale of public service announcements, and the sale of merchandise. These, as of now, are still insignificant.

An important transformation in the sector was the breaking up of the state's communications monopoly, and an even more significant force for the sector now is the increasing convergence of information and communication technologies (ICTs), such as the internet, telecommunications and broadcasting. ICTs have been responsible for the emergence of new information services and the Information Society.

\section{THE IMPACT OF TECHNOLOGY}

Over the last decade, changes in conventional media (newspaper, television, radio and magazine) have led to changes in consumer behavior. Digital media has made possible new ways of accessing content that can be transmitted and distributed much more easily. The population can now watch content anywhere and any time. (KATZMAN, 1974). We can also observe growing investments in Internet TV and online media, because audiences and revenue are migrating to these new outlets.

In fact, according to Hoynes, "[...] in much the same way that television was in the 1960 s, new digital media are now heralded as potential sites for enhancing our communication environment by providing opportunities for citizens to participate in public life." (MCCAULEY et al., 2002, p. 42). These changes give public broadcasters the possibility of thinking about the future of the sector in an era of multimedia conglomerates. In 2011, Internet access in Brazil reached 46.5 percent of the population, which will give rise to new possibilities in the Brazilian media. (INSTITUTO BRASILEIRO DE GEOGRAFIA E ESTATÍSTICA, 2012). 
The Internet is changing people's behavior regarding media; everyone can create and distribute content. They can also go to the websites of established newspapers and television and radio stations, as well as to new outlets such Netflix, Hulu, Vimeo and YouTube, which are available on the Internet. Attractive and interactive digital media is a challenge for public broadcasters because their audiences have many more media options. (ENLI, 2008). In this respect, Enli is concerned that public service content delivered digitally over the Internet may have the capacity to reach an entire nation, and thus limit the commercial potential of a channel's more targeted broadcasting. Given all these technological changes, governments need to change as well to take advantage of these technologies for the cultural and educational wellbeing of the population. The countries with high communication revenues and a more organized public broadcasting services are also the countries that show significant growth in the digital media field. Governments today need to consider the possibility of supporting multi-platform formats to fortify their public broadcasting program offerings in the age of convergence.

The United States, for example, has a digital communication policy with strategies aimed to grow Digital Public Television. (NG; NAN; VAN MALSSEN, 2010). Their goal is to offer the American population free access to a wide variety of content that could be archived and searched for reference/research purposes through of variety of platforms. The government, in collaboration with industry, expects the service to be interactive, to grow, to survive these new technologies and to be more attractive to the population.

In the presence of convergence and technological advances, how will public media content in the U.S. and Brazil be affected? This is an important question and we will present some data about the manner in which the population is now accessing content and how that might affect the manner in which governments should provide and finance educational, cultural and state content.

YouTube is a good example of how the ways in which people consume video content have changed. Because of online video hosting sites like YouTube and Vimeo, for example, we can now find a new generation of users who exhibit different viewing behavior. These sites can be used for research and community building and as spaces for self-expression. They host videos produced by users and other enterprises that can be categorized into channels. Netflix, 
another new media outlet, is now developing television series available to consumers, who are charged a monthly fee. The consumer can instantly watch unlimited movies and television episodes streamed over the Internet. According to its website, Netflix has approximately 26 million subscribers in the U.S., and 37 percent of the data circulation on the American Internet tracks through this outlet. (STATISTA, 2016). Certainly, this new service can negatively impact a traditional cable television company, because with this new technology, a consumer can get any movie (for the most part) any time they want.

Another example is Hulu, created by NBC and Fox, with the goal of making movies and series available on the Internet. On this website, all of the content of both companies can be watched any time and anywhere, sometimes requiring the user to pay a fee.

In the U.S., Roku, Chromecast and Amazon's FireTV are options that enable viewers to watch Internet videos on their televisions. With a small amount of equipment connected to the user's television, consumers have access to numerous Internet video channels. They can also buy or rent movies and TV series from multiple content sites, from traditional, as well as new, producer and distributors of content, including users. The users need only to buy the equipment and subscribe to the content they want.

For public broadcasters to survive the digital revolution, they will need to adapt, by investing in the technologies that suit their audiences.

\section{TECHNOLOGY AND VIEWING HABITS OF THE U.S. AND BRAZILIAN POPULATION}

In this section, we present the results of a survey of users that was conducted in both Brazil and the United States. The objective was to determine the extent to which users in both countries have adopted technologies that deliver video content. The construction of the survey was based on well-known technology adoption theories. It should be noted, nonetheless, that the objective of the survey was not to test the validity of the theories, but to get a sense of where the populations of both the U.S. and Brazil stood with respect to their ability and desire to transition to an online venue for public televion. The following discussion briefly describes each of the theories and the results of the survey for both countries. 
- Technology and digital divide issues (TDD)

Research in this area focuses primarily on access to infrastructure and users' ability to use it.

With the increasing use of the Internet for social, economic, educational and government services, it has become a priority for governments to expand access. However, some governments have been more successful than others. For the purpose of this paper, we focus on two types of video access: broadband and mobile.

Broadband access in Brazil reaches 10 percent of the population, through a fixed network. . In the United States, broadband access reaches approximately a third of the population. (INTERNATIONAL TELECOMMUNICATION UNION, 2014). Because a wired broadband infrastructure is much more expensive to construct, many developing countries rely much more on their mobile infrastructure. In Brazil, people typically have more than one phone, and penetration has reached 135 percent because some people have more than one sim card. (INTERNATIONAL TELECOMMUNICATION UNION, 2014). Developed nations have also embraced cellular technologies; in the United States, penetration is 95 percent.

However, having access does not mean that people know how to use a technology. This is particularly important because there are specific applications and sites that people need to be aware of to be able to watch video on their computers or mobile devices. Gráfico 3 shows the results of our survey regarding access and digital literacy, which we believe are both necessary if people are to feel comfortable watching programs online.

Answers to the surveys were based on a five point Likert scale from strongly agree $(\mathrm{SA}=1)$ to strongly disagree $(\mathrm{SD}=5)$. As can be noticed from the questions we developed, we wished to determine whether users not only have access, but also have the ability to find content. As can be seen from the results, we found that the majority of the respondents in the United States owned a computer (100 percent agreed or strongly agreed). In Brazil, even with the significantly lower penetration, a great percentage of the respondents indicated that they also owned a computer (88 percent agreed or strongly agreed). This shows, to a certain extent, that computers are reaching commodity status in Brazil, a trend that is likely to continue. 
However, having a computer is not enough for people to watch video content. For public channels to be effective at reaching audiences online, people need access to the Internet at home. In our survey, the majority of respondents in the U.S. indicated that they had access to the Internet at home (100 percent); the number is not much different in Brazil, where 88 percent of the respondents indicated that they had access at home.

There is another important component to consider regarding online television, and that is users' knowing how to do it. In our survey, two items tried to capture this notion: (1) I know how to find TV news on the Internet, and (2) I know how to find educational programs on the Internet. Please note the emphasis on educational programming and news, as we assumed that public television involves a public benefit component. In the United States, all of the respondentes strongly agreed or agreed with those two statements. In Brazil, we also found evidence of good digital literacy, with 75 percent strongly agreeing or agreeing with the first statement, and 75 percent of the respondents strongly agreeing or agreeing with the second statement.

Gráfico 3 - TDD model question and results

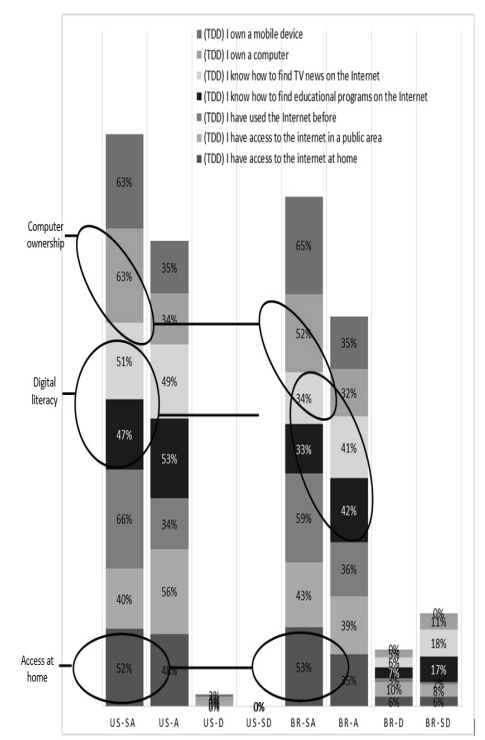

Source: Prepared by the authors. 


\section{- The Technology Acceptance Model (TAM)}

The Technology Acceptance Model has a long history, and many scholars have used it to determine whether or not a technology will be successful and how popular it will be. The theory originated with. (DAVIS; BAGOZZI; WARSHAW, 1989). It included two main components: perceived usefulness and perceived ease of use. In our case, we wanted to determine the effects of ease of use, as regards the use of mobiles and computers for watching TV. Usefulness, the extent to which watching TV online is helpful to people, would normally be determined in terms of the attributes of the technology. In this case, we were trying to capture the ways in which TV can be useful on a computer, which gives people the ability to watch programs at any time, from anywhere they have connectivity.

To some extent, a few components of the Technology Acceptance Model overlap with the access and literacy framework we presented before. For example, when we asked about users' ability to operate their computers and mobile devices, we found that in the U.S., most respondents agreed that it was easy to watch TV on their computers ( 71 percent) and more than half (55 percent) agreed that it was easy on their mobile devices. From these responses, if we assume that both are easy, the respondents seem to prefer the larger screen. In Brazil, the results reflect the manner in which the population accesses the Internet. The majority of respondents indicated (42 percent strongly agreed and 15 percent agreed) that it was easy to watch TV on their mobile devices. The opposite was the case for computers, where the majority disagreed (42 percent strongly disagreed and 18 percent disagreed) that it was easy to watch TV on their computers. It is possible that this is because the population has more access to mobile networks than to broadband.

Regarding the helpfulness of the ability to watch TV on their computers or mobile devices, the vast majority of respondents in the U.S. strongly agreed or agreed (17 percent and 69 percent respectively). In Brazil, we still found that the respondents did not find it helpful to watch programs on their mobiles (37 percent strongly disagree and 18 percent disagree) or their computers ( 47 percent strongly disagree and 19 percent disagree). This could be a reflection of the fact that content in Brazil has not yet reached a critical mass on the Internet. However this may change, as companies like Netflix launch their services worldwide. 
Another factor in the Enhanced Technology Acceptance Model (TAME) is the influence of friends on a person's decision to adopt a certain technology, or not (see Gráfico 4). In the United States, most people have family or friends who watch TV on their computers or mobile devices. In Brazil, the opposite is the case. The vast majority strongly disagreed or disagreed with the statement that friends or family watch TV on their computers (44 percent and 24 percent, respectively) or on their mobile devices (44 percent strongly disagreed and 21 percent disagreed). Given that there is high penetration of both mobile and broadband networks in the U.S., it is not surprising that more respondents there know people who use computers and phones to watch TV. In Brazil, while mobile penetration is high, this is not yet the norm.

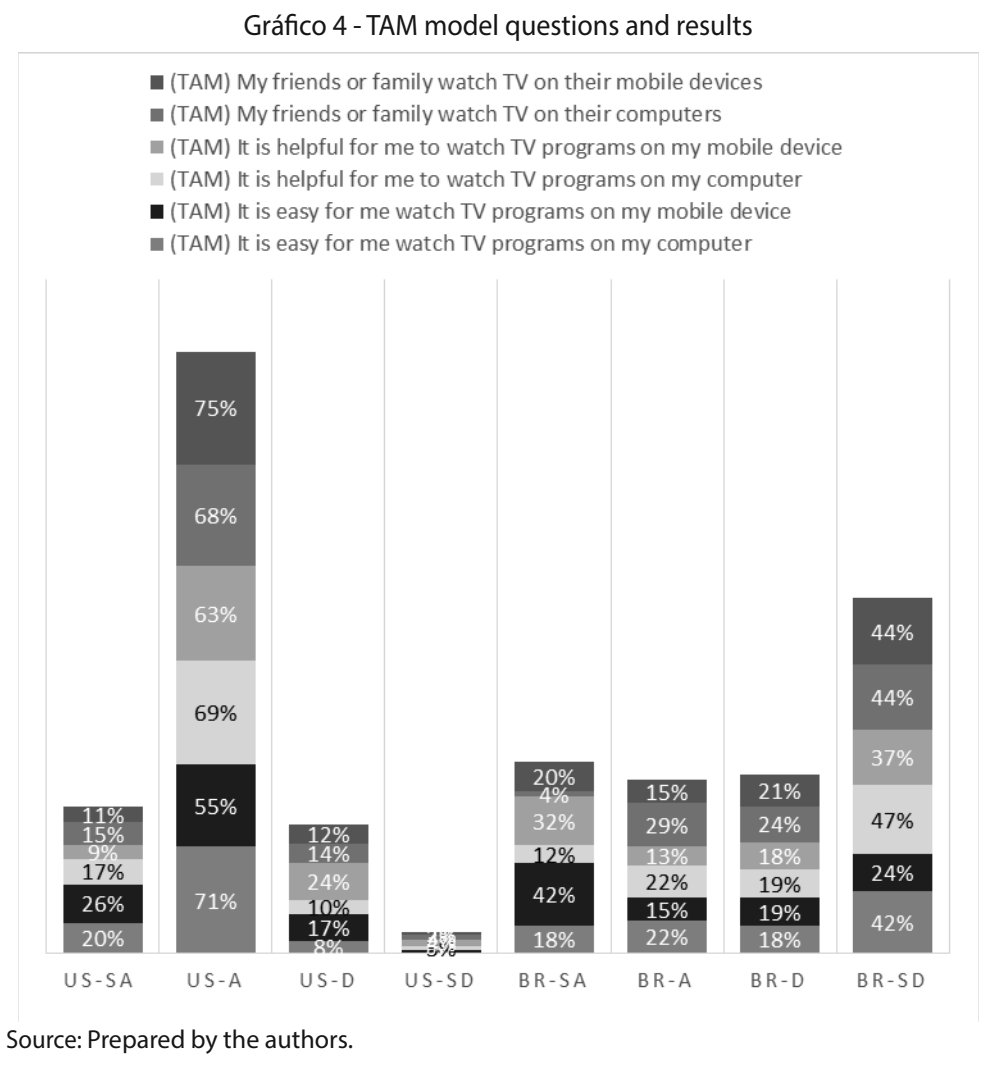


- The Innovation Diffusion Theory (IDT)

Up to this point, we have described two factors that can affect a person's willingness to adopt a technology: access (TDD), and elements of the technology that can make it useful and easy to use (TAM). Using the Innovation Diffusion Theory as a framework, we wished to determine users' preferences for the future. In this case, this theory tries to capture the preferences of a people and their desire to use a technology. This is important for us because our ultimate objective is to present policy recommendations on the basis of the history of public broadcasting in these two countries, while taking into consideration future trends.

Here, the most significant factor is not whether people are watching television on their mobile devices and computers, but whether they prefer watching them with these technologies rather than on traditional television. It is this preference that will determine whether the digital world prevails.

The data we collected from the survey (see Gráfico 5) indicates that most US respondents liked watching TV on their computer (77 percent strongly agreed or agreed) and their mobile phone (70 percent strongly agreed or agreed), and preferred watching TV on their computer (54 percent strongly agreed or agreed) and mobile phone (53 percent strongly agreed or agreed) compared to watching on conventional television sets.

Preferences and desires, however, differed in Brazil. While most respondents still did not like watching TV on their computer (66 percent strongly disagreed or disagreed) and mobile phone (57 percent strongly disagreed or disagreed), and did not prefer watching TV on their computer (90 percent strongly disagreed or disagreed) or mobile phone (29 percent strongly disagreed or disagreed), the trend may be changing, because there was also a good number of respondents who indicated that they would like to watch TV on their computer (34 percent strongly agreed or agreed) or mobile phone (34 percent strongly agreed or agreed) or who would prefer to watch TV on their computer (10 percent strongly agreed or agreed) or mobile phone (71 percent strongly agreed or agreed). This shows that there is at least a desire for respondents in Brazil to watch TV on their mobile devices. 
Melissa S. Moreira Rabelo | Martha Garcia-Murillo | Carlos Agostinho Couto

\section{Gráfico 5 - IDT model questions and results}

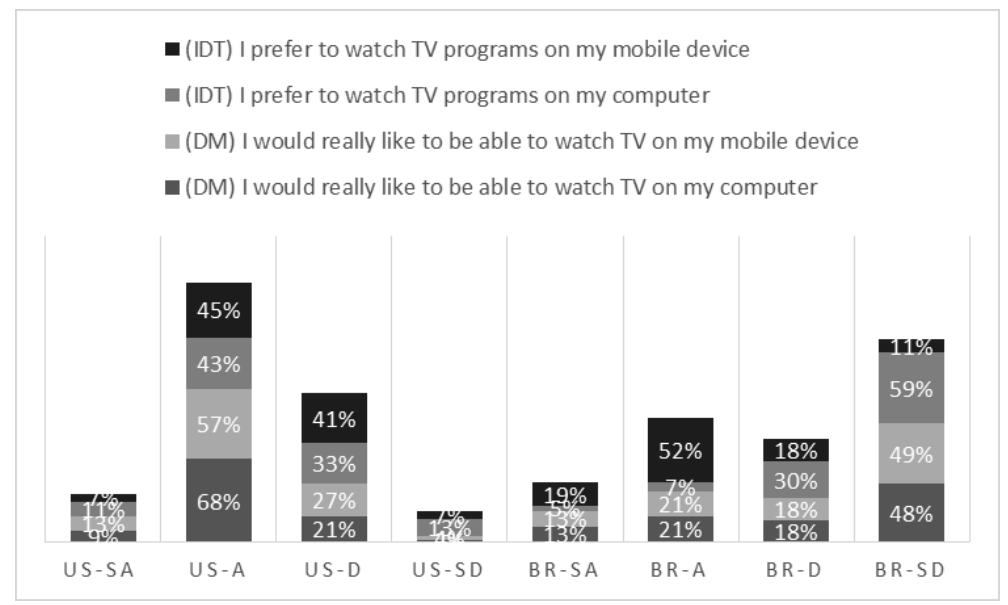

Source: Prepared by the authors.

The trend that we observe in the data matches the trend on Netflix in Brazil, which has grown since its introduction in 2011 at a rate of more than 200 percent (see Gráfico 6).

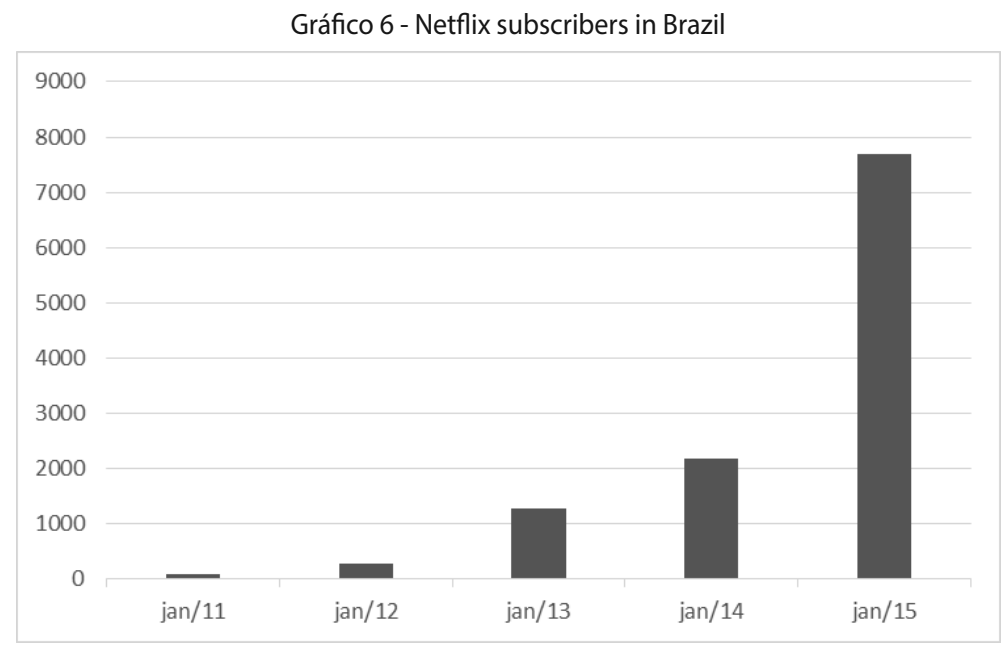

Source: STATISTA. Number of Netflix paying streaming subscribers in Brazil from 2011 to 2020. New York, 2015 Disponível em:<http://www.statista.com/statistics/324073/brazil-netflix-subscribers/>. Acesso em: 3 feb. 2016. 


\section{IMPLICATIONS FOR POLICY MAKING}

In the United States, it is clear that the population is already experiencing changes in behavior regarding their viewing habits. Access to broadband and the ability to operate ICT make it easier for them to watch television from the Internet. In Brazil, the main problem is access, and even though the majority of people interviewed were still not used to the idea of watching TV on their computer or phone, there are some signs of change.

Given these results, it would be desirable for governments and entities that operate public television and radio stations to invest not only in broadband access, but also in the creation of social service content that can be distributed and viewed through mobile phones or computers.

The policy, nonetheless, should be slightly different in the United States and Brazil. In the United States, the government needs to think about the value of keeping TV broadcasting, as people are begin to watch programs on demand from the Internet. The biggest concern for regulators is making sure that people have affordable and high-quality access to broadband.

In Brazil, the government will need to invest much more in broadband, but given the fact that Brazil still has limited public broadcasting as well as limited wired broadband, it may need a transition technology that will give the population access to public TV through other means, taking into consideration the fact that it will be a few years before the population has access to broadband and feels comfortable watching television on those devices. It might want to experiment above and beyond traditional media and allocate some of the broadcasting spectrum to Internet access and, in that way, accelerate access to the Internet.

\section{CONCLUSION}

The United States and Brazil have taken completely different approaches to access to public content. The United States government, faithful to its reliance on markets, provides little support for public television, which has forced stations around the country to rely on other sources of funding, such as foundations, underwriters and members of the public. The U.S. government, nonetheless, will have to make sure that broadband access is affordable and reliable. 
Brazil, although it is also moving towards a more market-based economy, provides almost total funding for public television. This is problematic because a lack of resources has prevented the government from fulfilling the mandate in its Constitution to provide free public television content to the entire population.

It is clear, nonetheless, that content is shifting onto the Internet in both countries. The U.S. population, as represented by the people we surveyed, prefer to watch programs on their computers or mobile phones. However, there are early signs that Brazil is moving in that direction as well. Given these trends, it will be important for the Brazilian government to continue to embrace free public television for all and to begin to invest in broadband access, as well as support the production of digital content that the population can access for free. It could potentially take advantage of the spectrum to do so.

The governments of both countries should realize the importance of broadband Internet access as a means to provide their populations with high-quality public television.

\section{REFERENCES}

BAMOUW, E. A tower in Babel: A history of broadcasting in the United States to 1933. New York: Oxford University Press, 1966.

BLAKELY, R. J. To serve the public interest: Educational broadcasting in the United States. New York: Syracuse University Press Syracuse, 1979.

BRASIL. Presidência da República. Decreto-Lei no 236, de 28 de fevereiro de 1967. Complementa e modifica a Lei número 4.117 de 27 de agosto de 1962. Diário Oficial da União. Brasília, DF, 28 de fev. 1967.

. República Federativa do Brasil. Constituição Federal de 1988. Brasília, DF, 1988.

CORPORATION FOR PUBLIC BROADCASTING. About Public Media. Washington, D.C., 2016. Disponível em: $<$ http://www.cpb.org/ aboutpb/>. Acesso em: 3 feb. 2016.

. Alternative Sources of Funding for Public Broadcasting Stations. Washington, D.C., 2012.

. Annual Report 2014. Washington, D.C., 2014. Disponível em:<http://www.cpb.org/annualreports/2014/>. Acesso em: 14 jan. 2014. 
PUBLIC BROADCASTING SERVICES IN THE UNITED STATES AND BRAZIL:

history, funding an new technologies D.C., 2013.

Public Broadcasting Revenue Fiscal Year 2013. Washington,

DAVIS, F. D.; BAGOZZI, R. P.; WARSHAW, P. R. User acceptance of computer technology: a comparison of two theoretical models. Management science, Singapore, v. 35, n. 8, p. 982-1003, 1989.

DOUGLAS, S. J. Inventing American Broadcasting, 1899-1922. Baltimore, MD: Johns Hopkins University Press, 1989.

ENLI, S. G. Redefining Public Service Broadcasting Multi-Platform Participation. Convergence, [S. 1.], v. 14, n. 1, p. 105-120, 2008.

GRIFFEN, D. Corporation for Public Broadcasting, Dynamic Inquiry Sessions on Public Service Media 2.0. Scottsdale, AZ: Advanced Strategy Center at Pinnacle Peak, 2009.

INSTITUTO BRASILEIRO DE GEOGRAFIA E ESTATÍSTICA. Síntese de indicadores sociais: uma análise das condições de vida da população brasileira. Rio de Janeiro, 2012. Disponível em:<http:// biblioteca.ibge.gov.br/visualizacao/livros/liv62715.pdf $>$. Acessado em: 15 jan. 2013.

INTERNATIONAL TELECOMMUNICATION UNION. Time series by country. Geneva, 2014. Disponível em: $<$ http://www.itu.int/en/ ITU-D/Statistics/Pages/stat/default.aspx>. Acesso em: 14 jan. 2014.

JAMBEIRO, O. Regulando a TV: uma visão comparativa no Mercosul. Salvador: EDUFBA, 2000. Disponível em: $<$ https:// repositorio.ufba.br/ri/bitstream/ufba/148/1/Regulando\%20a\%20TV. pdf $>$. Acesso em: 13 dez. 2013.

KATZMAN, N. The impact of communication technology: Promises and prospects. Journal of Communication, Medford, MA, v. 24, n. 4, p. 47-58, 1974.

LOPES, I. da S. Cultura política e democratização da comunicação no Brasil. In: ENCONTRO DA COMPOLÍTICA, 4., 2011, Rio de Janeiro. Anais... Rio de Janeiro: Compolitica, 2011. p. 1-16.

MCCAULEY, M. P. et al. Public broadcasting and the public interest. Armonk, NY: M.E. Sharpe, 2002.

MUNDY, G. 'Free-Enterprise' or 'Public Service'? The Origins of Broadcasting in the U.S., U.K. and Australia. Journal of Sociology, Hawthorn, v. 18, n. 3, p. 279-301, 1982. doi: $10.1177 / 144078338201800301$. 
NG, Y.; NAN, R.; VAN MALSSEN, K. Strategies for Sustainable Preservation of Born Digital Public Television. [S. 1.: s. n.], 2010.

ROWLAND, W. D. J. Continuing crisis in public broadcasting: a history of disenfranchisement. Journal of Broadcasting and Electronic Media, Philadelphia, PA, v. 30, n. 3, p. 251-274, 1986.

SANTOS, S. d.; SILVEIRA, É. d. Serviço publico e interesse publico nas comunicações. In: RAMOS, M. C.; SANTOS, S. d. (Eds.). Políticas de Comunicação: buscas teóricas e práticas. São Paulo: Paulus, 2007.

SHEPPERD, J. Infrastructure in the air: the office of education and the development of public broadcasting in the United States, 1934-1944. Critical Studies in Media Communication, Washington, D.C., p. 1-14, 2014. (ahead-of-print)

STATISTA. Number of Netflix paying streaming subscribers in Brazil from 2011 to 2020. New York, 2015 Disponível em: $<$ http://www. statista.com/statistics/324073/brazil-netflix-subscribers/>. Acesso em: 3 feb. 2016.

. Statistics and facts about Netflix. New York, 2016. Disponível em: $<$ http://www.statista.com/topics/842/netflix/>. Acesso em: 3 feb. 2016.

UNITED STATES. Subpart D - Corporation for Public Broadcasting. The Public Broadcasting Act. In: UNITED STATES CODE. Public Law 90-129. Washington, D.C., Sec. 396, nov. 1967.

WITHERSPOON, J. et al. The History of public broadcasting. Washington, D.C., 1987.

\section{NOTE:}

1 For a detailed account of the origins of the NAEB and the subsequent creation of public broadcasting, see Mundy (1982) and Shepperd (2014). 